\title{
RESULTS OF TESTS WITH NEW FUNGICIDES FOR THE CONTROL OF DAMPING-OFF OF TOBACCO IN PUERTO RICO
}

\section{A. Alvarez-García and Lidy López-Matos ${ }^{1}$ \\ INTRODUCTION}

Damping-off of tobacco seedlings continues to be a serious problem in Puerto Rico, particularly in periods of frequent rainfall. Results of previous work by the Plant Pathology Department have shown that damping-off can be controlled by weekly sprayings with Bordeaux Mixture (4-4-50). Formaldehyde and steam sterilization though effective to a certain extent, are not considered economically practical in our agricultural environment.

The importance of spraying for successful production of tobaco seedlings has been demonstrated time and again. The discovery and synthesis of new chemicals for disease control suggested that they be tested for damping-off.

\section{EXPERIMENTS IN 1950-51}

\section{At Aibonito}

During the 1950-51 season an experiment was made at the Tobacco Seed Farm in Aibonito. The soil type of the experimental field is a Juncos clay with a pH of 5.5. The site used was a low round hill with a gentle slope. The experimental lay-out for this test was a randomized block design, including six treatments and a check; each treatment and check was replicated six times. The seedbed was prepared under cheesecloth. The seed were sown on October 9.

The following fungicidal chemicals were tested: Fermate (65 percent Ferbam-ferric dimethyl dithiocarbamate); Dithane Z-78 (zinc ethylene bisdithiocarbamate); Parzate (zinc ethylene bisdithiocarbamate); Compound A (copper oxychloride); and Bordeaux Mixture (4-3-50). The carbamates were used at a rate of 2 pounds per 100 gallons of water. Water in equivalent amount was used for the checks.

The fungicidal suspensions were applied at rates of 1 and $1 \frac{1}{2}$ gallons per square yard, in the first and second weekly sprayings, respectively. In the third weekly spraying, and after, 2.5 gallons of fungicidal suspensions were applied per square yard. The treatments were discontinued after the seventh weekly spraying. The seedlings had then reached the transplanting stage.

The weather was favorable for damping-off development during the

${ }^{1}$ Plant Pathologist and Head of Department and Research Assistant in Plant Pathology, respectively, Agricultural Experiment Station, University of Puerto Rico, Río Piedras, P. R. 
growing period. The frequent rainfall kept the soil completely saturated most of the time.

The results indicate the importance of chemical spraying for disease control and show the relative efficacy of the chemical compounds tested.

The percentages of infection in each treatment are presented in table 1 .

The analysis of variance of the data collected shows that all treatments were significantly effective when compared with the check.

It should be mentioned that Bordeaux Mixture was slightly phytotoxic to very young plants, also that Fermate burned and caused about 10 percent

TABLE 1.-Results of using chemical fungicides for damping-off control at Aibonito, autumn 1950

\begin{tabular}{|c|c|}
\hline Fungicide & Percentage of infection ${ }^{1}$ \\
\hline Bordeaux Mixture..... & 1.98 \\
\hline Copper A Compound.......... & 2.50 \\
\hline 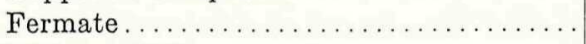 & 11.90 \\
\hline 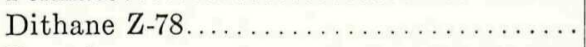 & 18.55 \\
\hline 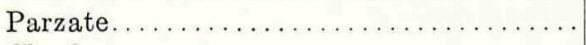 & 18.75 \\
\hline Check. . . . ..................... & 88.48 \\
\hline
\end{tabular}

${ }^{1}$ S. E. D. $=8.34$

L. S. D. (including Check):

At 5-percent point $=8.34(2.060)=17.18$

At 1 -percent point $=8.34(2.787)=23.25$

S. E. D. $=4.58$

L. S. D. (excluding Check):

At 5-percent point $=4.58(2.086)=9.55$

At 1-percent point $=4.58(2.845)=13.03$

of damage to 1-week-old seedlings, accompanied by a marked retardation of their growth. This retarding effect could be advantageous during wet seasons by reducing the number of spindled seedlings.

Fermate was, however, less phytotoxic to seedlings that had attained about 2 inches in height. Some injured seedlings recovered and became dark-green, sturdy, though somewhat dwarfed plants.

From the analysis of variance (excluding the Check) it can be seen that at the 1-percent level, Bordeaux Mixture, Copper A Compound, and Fermate were equally effective and significantly superior to Dithane Z-78 and Parzate.

At the 5-percent level, Bordeaux Mixture and Copper A Compound proved better than Fermate, Dithane Z-78, and Parzate.

It should be mentioned that the commercial seedbed at the Aibonito Farm was lost at this time because of a 100-percent infection. 


\section{At San Lorenzo}

The same design was used to test the chemicals at the San Lorenzo Seed Farm. The only difference in procedure was the application of 1 gallon of each suspension per square yard of seedbed. None of the chemicals was phytotoxic at the concentrations ( 2 pounds per 100 gallons) used for the

TABLE 2.-Results of using chemical fungicides for damping-off control at San Lorenzo, autumn 1951

\begin{tabular}{|c|c|}
\hline Fungicide & Percentage of infection ${ }^{1}$ \\
\hline Copper A Compound.................. & 11.36 \\
\hline Bordeaux Mixture.......... & 14.85 \\
\hline Fermate $2-100 \ldots \ldots \ldots \ldots \ldots$ & 37.72 \\
\hline Fermate $1-100 \ldots \ldots \ldots \ldots \ldots \ldots \ldots \ldots$ & 39.39 \\
\hline Dithane Z-78. . . . . . . . . . . . . . & 64.39 \\
\hline Check.............................. & 70.60 \\
\hline
\end{tabular}

${ }^{1}$ S. E. D. $=13.74$

L. S. D.: At 5-percent point $=28.68$

At 1-percent point $=39.12$

TABLE 3.-Results of using chemical fungicides for damping-off control at Caguas, 1951

\begin{tabular}{|c|c|}
\hline Fungicides & Percentage of infection ${ }^{1}$ \\
\hline Copper A Compound................. & 15.00 \\
\hline $\begin{array}{l}\text { Copper A Compound plus lime (half and } \\
\text { half } \ldots \ldots \ldots \ldots \ldots \ldots \ldots \ldots \ldots\end{array}$ & 15.94 \\
\hline Bordeaux Mixture . . . . . . . . . . . . . . & 16.51 \\
\hline 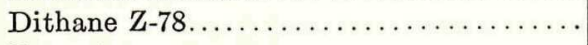 & 74.99 \\
\hline 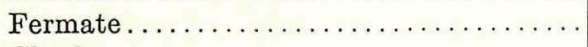 & 85.60 \\
\hline Check. . . . . . . . . . . . . . . . . . & 100.00 \\
\hline
\end{tabular}

${ }^{1}$ S. E. D. $=7.979$

L. S. D.: At 5-percent point $=16.64$

At 1 -percent point $=22.70$

carbamates and at (4-3-50) for Bordeaux Mixture. The soil used for the seedbed was a Las Piedras sandy-clay loam with a clay subsoil. The $\mathrm{pH}$ of the topsoil was 5.8 .

The percentages of infection per treatment are presented in table 2 .

According to the analysis of variance all the treatments with the exception of Dithane Z-78 and Fermate were significantly superior to the Check at the 1-percent level. Copper A and Bordeaux Mixture were significantly superior to Dithane Z-78 at the 1-percent level. Fermate was superior to the Check at 5-percent level. 


\section{At Caguas}

The same plot design was followed and the same treatments at the same rate and concentrations were used at Caguas. The soil used was a Caguas sandy-clay loam of $\mathrm{pH} 4.80$.

The results of the experiment are presented in table 3 .

According to this analysis Copper A Compound, Copper A Compound plus lime (powder treatment), and Bordeaux Mixture were significantly superior to Fermate, Dithane Z-78, and the Check at the 1-percent level. There was no significant difference between Copper A Compound spray, Copper A plus lime (half and half) and Bordeaux Mixture at the 5-percent and 1-percent levels.

Dithane Z-78 was significantly superior to Fermate at the 5-percent level. Dithane Z-78 was superior to the Check at the 1-percent level.

The rank of the fungicides in order of merit was: Copper A Compound, Copper A plus lime, Bordeaux Mixture, Dithane Z-78, and Fermate.

\section{DISCUSSION AND CONCLUSIONS}

Damping-off of tobacco cannot be absolutely erradicated in our soils but it can be controlled practically with chemical treatments. Copper in such forms as in Bordeaux Mixture and copper oxychloride was somewhat superior in keeping the infection at a minimum under most varying conditions of soil and climate.

The degree of efficacy of the various chemicals varies with the soil and the climatic environment at the time of the application. It is known that fungicidal chemicals differ in efficacy under varying agricultural conditions. This in part explains why there was less difference in efficacy at Aibonito and marked variation at San Lorenzo and Caguas.

On the basis of these tests in Aibonito, Caguas, and San Lorenzo it seems reasonable and practical to use any of the fungicides for control of the damping-off. However, it might be desirable under certain conditions to use two chemicals alternately. The retarding growth effect of Fermate could be advantageous during periods of frequent rainfall in order to avoid spindled growth. Spraying every other week with Copper A Compound and Fermate alternately would perhaps be very effective under such circumstances.

The use of chemicals in powder form (dusting) during wet periods is recommended because the use of sprays adds to the water content of the soil thus creating more favorable conditions for damping-off development.

The frequency of application must be considered. Mere weekly applications may be insufficient. Spraying or dusting should be practiced whenever necessary. During moderately wet periods spraying is acceptable, but dusting is preferable during very humid periods.

The phytotoxicity of the chemicals must be considered. Compound $\mathrm{A}$ is 
less soluble than Bordeaux Mixture, therefore less phytotoxic, and can be applied with less risk during the early growth of the seedlings. Bordeaux and Fermate are a little toxic under hot, humid conditions but not to the extreme of killing the plants.

A field test with seedlings taken from each respective treatment showed that the early phytotoxic effect of Bordeaux Mixture and Fermate had very little or no effect on the yield of leaf tobacco.

\section{SUMMARY}

1. Experiments for the comparative testing of new fungicidal chemicals for the control of damping-off of tobacco were performed at Aibonito, Caguas, and San Lorenzo.

2. In Aibonito, Bordeaux Mixture and Copper A Compound proved superior to Fermate, Dithane Z-78, and Parzate.

3. In San Lorenzo, Bordeaux Mixture and Copper A Compound also proved superior to Fermate, Dithane Z-78, and Parzate.

4. In Caguas, Bordeaux Mixture and Copper A Compound again proved superior to Dithane Z-78 and to Fermate.

5. All treatments, however, were practically effective in controlling damping-off.

\section{RESUMEN}

Con el propósito de comparar la eficacia de varios nuevos fungicidas con el caldo bordelés, para combatir la micosis del pie (sancocho) en los semilleros de tabaco, se realizaron varios experimentos en Aibonito, San Lorenzo y Caguas. El resultado de la experimentación ha demostrado que todos los fungicidas probados son prácticamente eficaces y dominan el "sancocho" de los semilleros de tabaco.

No obstante, los mejores resultados, en términos generales, fueron los conseguidos con los compuestos de cobre. 